\title{
Toxic dinoflagellates produce true grazer deterrents
}

\author{
Xu, Jiayi; Kiørboe, Thomas
}

Published in:

Ecology

Link to article, DOI:

10.1002/ecy.2479

Publication date:

2018

Document Version

Publisher's PDF, also known as Version of record

Link back to DTU Orbit

Citation (APA):

Xu, J., \& Kiørboe, T. (2018). Toxic dinoflagellates produce true grazer deterrents. Ecology, 99(10), 2240-2249. https://doi.org/10.1002/ecy.2479

\section{General rights}

Copyright and moral rights for the publications made accessible in the public portal are retained by the authors and/or other copyright owners and it is a condition of accessing publications that users recognise and abide by the legal requirements associated with these rights.

- Users may download and print one copy of any publication from the public portal for the purpose of private study or research.

- You may not further distribute the material or use it for any profit-making activity or commercial gain

- You may freely distribute the URL identifying the publication in the public portal

If you believe that this document breaches copyright please contact us providing details, and we will remove access to the work immediately and investigate your claim. 


\title{
Toxic dinoflagellates produce true grazer deterrents
}

\author{
JiAYi XU (D) $1,2,3$ and Thomas Kiørboe ${ }^{1}$ \\ ${ }^{1}$ Centre for Ocean Life, National Institute of Aquatic Resources, Technical University of Denmark, Kemitorvet, 2800 Kgs. Lyngby, Denmark \\ ${ }^{2}$ State Key Laboratory of Estuarine and Coastal Research, East China Normal University, 200062 Shanghai, China
}

\begin{abstract}
Many phytoplankton species produce toxic substances, but their functional role is unclear. Specifically, it remains uncertain whether these compounds have a toxic or deterrent effect on grazers; only, the latter is consistent with toxins as defensive tools. Here, we show that 10 of 12 species or strains of toxic dinoflagellates were consumed at lower rates than a similarly sized nontoxic dinoflagellate by a copepod. Through video observations of individual prey-grazer interactions, we further demonstrate that the dominating mechanism is through capture, examination, and subsequent rejection of vital cells, that is, a true deterrent effect that offers a straightforward explanation to its evolution. We argue that the diversity of grazer responses to toxic phytoplankton reported in the literature, including toxic effects, and the high diversity of toxin profiles between strains of the same phytoplankton species reflect different stages of an ever-ongoing evolutionary arms race, facilitated by rapid adaptation of grazers to toxic substances. We further argue that defensive toxicity requires a chemical signal exterior to the cell that informs the grazer about the toxicity of the cell. The signal can be the toxin itself or just an aposematic signal of toxicity. In the former case, allelochemical effects may emerge at high cell concentrations as a nonadaptive side effect of a predator defenses.
\end{abstract}

Key words: coevolution; feeding behavior; grazer deterrent; prey rejection; Temora longicornis; toxic dinoflagellates.

\section{INTRODUCTION}

Many species of phytoplankton produce substances that negatively impact other organisms. These substances may be allelochemical compounds that are released into the environment and may affect competing phytoplankton, potential grazers, potential prey, and other organisms (Tillmann and John 2002, Tillmann 2003, Granéli and Hansen 2006, Blossom et al. 2012, John et al. 2015). Alternatively, such substances may be intracellular compounds that directly impact only organisms that consume the phytoplankton (see reviewed by Turner 2014, Uye and Takamatsu 1990, Xu et al. 2017). Chemical warfare and defense are well described and understood in terrestrial plants that are sedentary and can afford sacrificing a few leaves to deter grazers (Wittstock and Gershenzon 2002). Terrestrial models of chemical warfare and defense do not, however, necessarily apply well to phytoplankton. A toxic phytoplankton cell consumed by a grazer may benefit its genetically identical siblings in a population consisting of clonal cells (Thornton 2002), but phytoplankton populations are typically genetically diverse (Alpermann et al. 2010) and cheaters that do not produce the substance as well as competing species may be equally benefitted. Thus, cheaters may invade and this appears not to be an evolutionary stable strategy (ESS) (West et al. 2006, Lee et al. 2010). Only in toxic cells with grazer-deterrent effects can toxicity be considered a true defense. However, most incubation experiments have been unable to distinguish toxic from deterrent effects (Turner 2014). Among experiments that have been able to separate the two effects, only a few have demonstrated selection

Manuscript received 22 March 2018; revised 11 June 2018; accepted 10 July 2018. Corresponding Editor: Alan L. Shanks.

${ }^{3}$ E-mail: sjxu@aqua.dtu.dk against toxic cells (Teegarden 1999, Selander et al. 2006), while many reports demonstrate toxic effects (Sykes and Huntley 1987, Lasley-Rasher et al. 2016, Rasmussen et al. 2017, Xu et al. 2017, 2018). Similarly, leaked substances with allelopathic effects on competitors and predators are "public goods" that benefit not only the producer but also nontoxic species and thus do not constitute an ESS (Lewis 1986, Driscoll et al. 2016). Understanding of the evolution of the production of toxic substances in phytoplankton is incomplete, and toxin functional roles remain unclear. The fact that the toxic compounds may often negatively impact grazers (as reviewed by Turner 2014), and that the production of the substances may be induced or upregulated in the presence of grazers due to chemical signals (Selander et al. 2006, 2012, 2015) strongly suggests; however, that in many cases, these substances play a defensive role.

One key to further the understanding of the function and evolution of harmful substances as defense tools is to examine the impact at the individual level as this may allow one to distinguish toxic from deterrent effects. There have been only a handful of studies that have examined the effects of a few species of toxic algae on copepod grazers at the individual level. These studies have revealed a number of different responses: (1) aberrant swimming or appendage behavior in copepods subsequent to exposure to toxic algae (Sykes and Huntley 1987, Cohen et al. 2007, Hong et al. 2012, LasleyRasher et al. 2016, Xu et al. 2018), likely a consequence of the consumption of some cells and subsequent intoxication and reduced feeding rate; (2) cells are captured but subsequently regurgitated (Sykes and Huntley 1987, Xu et al. 2017), resulting in mortality of ingested cells of toxic algae, initially similar to that of nontoxic cells, but with reduced benefits to the grazer and reduced grazing overall in the longer term; and (3) toxic cells are captured but subsequently rejected, leaving the toxic cell intact and vital $\mathrm{Xu}$ 
et al. 2017, 2018). While the grazers' behavioral responses in all cases lead to reduced grazing on toxic cells, only the third response is a true grazing deterrent response that yields the toxic cells with a clear individual advantage and that can be easily understood as a defense mechanism.

The above studies involved a relatively narrow selection of species and strains of dinoflagellates, and the different responses are not immediately comparable due to the use of different approaches. However, a genuine grazer-deterrent effect was demonstrated in only one case (Xu et al. 2017). Copepods are among the main grazers of dinoflagellates in the ocean, and most toxic species in the ocean are dinoflagellates (Turner 2014). To further explore the diversity of copepod behavioral responses to algae that produce toxic substance, we here examine, by a consistent approach, the effects of a diverse selection of 12 different species and strains of dinoflagellates on the foraging behavior of the copepod Temora longicornis. Through direct video observations, we demonstrate that the highly variable consumption rates observed between species and strains are accomplished by various mechanisms, but that the dominating response of the copepods to toxic algae is elevated rejection of captured cells, that is, a true grazer-deterrent effect that is immediately compatible with the role of toxic substances as a defense mechanism.

\section{Materials And Methods}

\section{Algal species and their toxin profiles}

The 13 dinoflagellate test species/strains varied somewhat in size, between 15 and $35 \mu \mathrm{m}$ equivalent spherical diameter (Table 1), and they produce very different toxins. Alexandrium tamarense produces paralytic shellfish poisoning (PSP) toxins, a group of neurotoxins (Turner and Tester 1997, Cembella 1998, Turner 2014), and unknown lytic compounds (Tillmann et al. 2009). Toxicity profiles vary substantially between strains (Ichimi et al. 2002, Tillmann et al.
2009). Alexandrium pseudogonyaulax produces goniodomin A (GDA), another neurotoxin (Triki et al. 2016, Xu et al. 2017), and special mucus traps that are able to immobilize and aggregate prey cells (Blossom et al. 2012). The mixotrophic Karlodinium armiger produces ichthyotoxic karmitoxin, a lytic compound with cytotoxic effects on gill cells of rainbow trout, and that immobilize and kill copepods (Rasmussen et al. 2017). Karenia brevis can produce brevetoxins $(\mathrm{PbTx})$, a potent ichthyotoxic neurotoxins (Naar et al. 2007), brevetoxin antagonists (Baden et al. 2005, Satake et al. 2009), and hemolytic toxins (Neely and Campbell 2006). Karenia mikimotoi produces gymnocin-A, gymnocinB, and some hemolytic toxins (Satake et al. 2002, 2005, Neely and Campbell 2006). Karenia selliformis is most closely related to $K$. brevis and $K$. mikimotoi and produces gymnodimines, brevetoxins, and hemolytic compounds (Seki et al. 1995, Miles et al. 2000, Tatters et al. 2010). The genus Dinophysis is known as the main source of okadaic acid (OA) and its derivatives, dinophysistoxins (DTX), while Dinophysis acuminata mainly produces pectenotoxin (PTX) rather than OA (Kamiyama and Suzuki 2009). In most cases, the effects of the various toxins on grazers are unknown. Protoceratium reticulatum served as a nontoxic control.

All the cultures were grown on $\mathrm{B} 1$ medium at $16^{\circ} \mathrm{C}$, a salinity of 32 , and an irradiance of $100-150 \mu \mathrm{mol}$ photos $\cdot \mathrm{m}^{-2} \cdot \mathrm{s}^{-1}$ on a $12 \mathrm{~h}$ light-dark cycle. The mixotrophic $D$. acuminata was additionally fed with the ciliate Mesodinium rubrum. We stopped feeding five days before experiments to have a monoculture of $D$. acuminata for the experiments. All algae for experiments were collected in the exponential growth phase.

Samples for toxin measurements of A.tamarense, A. pseudogonyaulax, $K$. brevis, $D$. acuminata, and $P$. reticulatum were taken just prior to experiments, and the results shown in Table 2. Approximately $20 \mathrm{~mL}$ of $A$. tamarense, A. pseudogonyaulax, $K$. brevis, and $P$. reticulatum cell culture $(\approx 20,000$ cells $)$ was centrifuged at $2,150 \times \mathrm{g}$ for $15 \mathrm{~min}$. Cell pellets were resuspended after removing most of the

TABLE 1. Phytoplankton used as prey for Temora longicornis including the strain number and isolation location.

\begin{tabular}{|c|c|c|c|c|c|}
\hline Algae & Strain & No. & Origin & $\mathrm{ESD} \pm \mathrm{SD}(\mu \mathrm{m})$ & $\begin{array}{l}\text { Initial concentration } \\
(\text { cells } / \mathrm{mL})\end{array}$ \\
\hline \multirow[t]{3}{*}{ Alexandrium tamarense } & Alex 5 & S1 & North Sea of Scotland & $33.8 \pm 0.5$ & 77 \\
\hline & K-1471 & $\mathrm{S} 2$ & Offshore of Lysekil, Sweden & $25.0 \pm 2.3$ & 192 \\
\hline & CCMP 1598 & $\mathrm{~S} 3$ & Daya Bay, China & $30.0 \pm 4.4$ & 101 \\
\hline \multirow{2}{*}{$\begin{array}{l}\text { Alexandrium } \\
\text { pseudogonyaulax }\end{array}$} & K-1344 & S4 & Limfjorden, Denmark & $35.0 \pm 5.4$ & 67 \\
\hline & K-1345 & S5 & Limfjorden, Denmark & $31.8 \pm 4.8$ & 88 \\
\hline Karlodinium armiger & K-0668 & S6 & Alfacs Bay, Spain & $15.3 \pm 3.1$ & 595 \\
\hline Karenia selliformis & K-1319 & S7 & Gulf of Gabès, Tunisia & $20.8 \pm 4.2$ & 349 \\
\hline \multirow[t]{2}{*}{ Karenia brevis } & CCMP 2229 & S8 & Offshore of Manasota Key, USA & $23.0 \pm 5.2$ & 286 \\
\hline & CCMP 718 & S9 & Florida, USA & $25.5 \pm 4.2$ & 168 \\
\hline \multirow[t]{2}{*}{ Karenia mikimotoi } & СCMP 429 & $\mathrm{~S} 10$ & Sutton Harbour, United Kingdom & $26.4 \pm 5.1$ & 195 \\
\hline & K-0260 & $\mathrm{S} 11$ & Oslofjorden, Norway & $23.3 \pm 5.1$ & 245 \\
\hline Dinophysis acuminata & & $\mathrm{S} 12$ & Denmark $\dagger$ & $33.5 \pm 11.3$ & 89 \\
\hline Protoceratium reticulatum & CCMP 1889 & $\mathrm{~S} 13$ & Friday Harbor, USA & $32.0 \pm 2.3$ & 84 \\
\hline
\end{tabular}

Notes: Equivalent spherical diameters (ESD; mean \pm SD) are based on measurements of linear dimensions 20 cells of each species and by assuming spherical or spheroid shapes (Hillebrand et al. 1999). The initial cell concentration is that used in the video observation. Cell cultures were obtained from Alfred Wegener Institute, Germany; National Center for Marine Algae and Microbiota; Scandinavian Culture Collection for Algae and Protozoa; and Marine Biological Section, University of Copenhagen.

$\dagger$ Cultures were originally isolated from seven different locations in Denmark (Nielsen et al. 2012). 
TABLE 2. Toxin profiles and contents of algae.

\begin{tabular}{|c|c|c|c|c|c|c|c|c|c|}
\hline \multirow[b]{2}{*}{ Algae } & \multirow[b]{2}{*}{ Strain } & \multirow[b]{2}{*}{ No. } & \multicolumn{6}{|c|}{ Toxicity (pg/cell) } & \multirow[b]{2}{*}{ YTX } \\
\hline & & & $\mathrm{PSP} \dagger$ & GDA & $\mathrm{PbTx}$ & $\mathrm{OA}$ & DTX & PTX2 & \\
\hline \multirow[t]{3}{*}{ Alexandrium tamarense } & Alex 5 & $\mathrm{~S} 1$ & 44.1 & - & - & - & - & - & - \\
\hline & K-1471 & $\mathrm{S} 2$ & ND & - & - & - & - & - & - \\
\hline & CCMP 1598 & S3 & ND & - & - & - & - & - & - \\
\hline \multirow[t]{2}{*}{ Alexandrium pseudogonyaulax } & K-1344 & $\mathrm{S} 4$ & - & 15.6 & - & - & - & - & - \\
\hline & $\mathrm{K}-1345$ & S5 & - & 19.8 & - & - & - & - & - \\
\hline Karlodinium armiger & K-0668 & S6 & - & - & - & - & - & - & - \\
\hline Karenia selliformis & K-1319 & S7 & - & - & - & - & - & - & - \\
\hline \multirow[t]{2}{*}{ Karenia brevis } & CCMP 2229 & S8 & - & - & ND & - & - & - & - \\
\hline & CCMP 718 & S9 & - & - & ND & - & - & - & - \\
\hline \multirow[t]{2}{*}{ Karenia mikimotoi } & ССМР 429 & $\mathrm{~S} 10$ & - & - & - & - & - & - & - \\
\hline & K-0260 & $\mathrm{S} 11$ & - & - & - & - & - & - & - \\
\hline Dinophysis acuminata & & $\mathrm{S} 12$ & - & - & - & ND & ND & 19.1 & - \\
\hline Protoceratium reticulatum & CCMP 1889 & $\mathrm{~S} 13$ & ND & ND & - & - & - & - & ND \\
\hline
\end{tabular}

Notes: PSP, Paralytic shellfish poisoning toxins; GDA, Goniodomin A; PbTx, Brevetoxin; OA, Okadaic acid; DTX, Dinophysistoxin; PTX2, Pectenotoxin-2; YTX, Yessotoxin; -, means toxins were not measured; ND, means toxins were not detected.

$\dagger$ Values were calculated as saxitoxin equivalents (pg STXeq/cell), including saxitoxin (STX) and four derivatives (NEO, GTX2/3, GTX1/ 4 , and $\mathrm{C} 1 / 2)$.

supernatant and transferred to microcentrifuge tubes with $1 \mathrm{~mL}$ B1 medium. Samples were then centrifuged again at $3,200 \times \mathrm{g}$ for $15 \mathrm{~min}$. All the cell pellets and supernatants were collected ( $\mathrm{Xu}$ et al. 2017). Cells of D. acuminata were sampled in triplicate by centrifuging $0.5 \mathrm{~mL}$ subsamples $(\approx 1,000$ cells) in spin filters at $400 \times \mathrm{g}$ for $2 \mathrm{~min}$ (Nielsen et al. 2013). Cell pellets and filtrates were collected. Cell concentrations in the initial algal sample and the supernatant (or filtrates) were counted to quantify exact cell numbers in pellets for toxin measurement. Dry samples were kept at $-20^{\circ} \mathrm{C}$, and all further analyses were conducted at Alfred Wegener Institute, Germany (as described in detail in Nielsen et al. 2013, Suikkanen et al. 2013, Sala-Pérez et al. 2016, Xu et al. 2017; B. Krock, unpublished manuscript).

\section{Copepods}

The feeding-current feeding copepod, Temora longicornis, was collected in Øresund, Denmark $\left(56^{\circ} 04^{\prime} \mathrm{N} ; 12^{\circ} 38^{\prime} \mathrm{E}\right)$, and kept in continuous cultures in darkness at $15^{\circ} \mathrm{C}$, a salinity of 32, and fed with a mixed diet of Akashiwo sanguinea, Heterocapsa triquetra, Prorocentrum minimum, Thallasiosira weissflogii, and Rhodomonas salina. Animals for experiments were of $\mathrm{F} 3$ + generation.

For each treatment, approximately 15 adult females were tethered to their dorsal surface with a short length of human hair by a small drop of cyanoacrylate glue. Tethered copepods were placed in filtered sea water and starved overnight at the same temperature and salinity as the cultures. Tethered copepods can live for many days, feeding, defecating, and producing eggs, apparently unaffected by the tether.

\section{Experimental design and setup}

Tethered copepods in good condition were attached to a plastic pipette by the other end of the hair and connected to a micromanipulator. Each individual was submerged in a $10 \times 10 \times 10 \mathrm{~cm}^{3}$ aquarium with $900 \mathrm{~mL}$ filtered sea water and a single prey species. The initial volume concentration of algae was the same in all experiments, approximately $1.4 \times 10^{6} \mu \mathrm{m}^{3} / \mathrm{mL}$, resulting in different cell number concentrations (Table 1). The water was gently stirred to keep cells in suspension. The aquarium was placed between an infrared light source and the camera equipped with lenses to yield a field of view of approximately $2.5 \times 1.6 \mathrm{~mm}^{2}$. Feeding behaviors of copepods were recorded by a high-speed camera (Phantom V210; Vision Research, Wayne, New Jersey, USA) that was connected to both a computer for saving short high-speed sequences $(2,200$ frames/s, resolution: $1,280 \times 800$ pixels) and a tape recorder for saving of longer low-speed videos ( 25 frames/s, resolution: $720 \times 576$ pixels $)$. The experiments were conducted in a dark, constant temperature room at $16^{\circ} \mathrm{C}$

The experiment started when prey cells were added to the aquarium. During the subsequent 4 h, 5-min low-speed video sequences were recorded every $30 \mathrm{~min}$ and one to three high-speed sequences of up to $2.5 \mathrm{~s}$ duration were recorded every two hours. After $24 \mathrm{~h}$, three low-speed videos and two high-speed videos were recorded within $1 \mathrm{~h}$. Each treatment had three replicates.

Capture, ingestion, and rejection events were enumerated from every five-minute low-speed video, as described earlier (Xu et al. 2017). The fraction of time that the copepod was beating its feeding appendages was calculated from the number of frames in which the appendages were beating during the entire five-minute period. From high-speed videos, the beating frequency of the feeding appendages was estimated and details of feeding behaviors were observed. Clearance rate was calculated as the capture rate divided by prey concentration. Images were analyzed with ImageJ (version $1.51 \mathrm{~h}$; National Institutes of Health, Bethesda, Maryland, USA) and Phantom Cine Viewer (version 2.6; Vision Research).

Statistical differences over time and between prey species in clearance rate, ingestion rate (converted to biomass ingested), beating frequency, and fraction of time beating were tested with one-way or two-way ANOVAs followed by 
Holm-Sidak post hoc test. The assumption of normality was tested. The difference in fraction of cells rejected after being captured between treatments was compared by the $95 \%$ Wilson score interval.

\section{RESUlTS}

\section{Ingestion rate}

Upon adding phytoplankton to the copepods, their ingestion rates decreased rapidly during the first two hours of observation for some of the strains (Appendix S1: Fig. S1 and Appendix S2: Fig. S1) but subsequently did not vary with time (two-way ANOVA, $P=0.407$ ). In the following, we thus compare averages for the observations during the last $22 \mathrm{~h}$. Ingestion rates varied by a factor of up to 20 between prey species (Fig. 1, two-way ANOVA, $P<0.001$ ). The nontoxic control prey, $P$. reticulatum (S13), was ingested at the highest rate and $A$. pseudogonyaulax strains (S4 and S5) and $K$. brevis strains (S8 and S9) (Table 2) at the lowest rates, with the other strains in between. Variation in ingestion rate between prey can be due to different mechanisms, that is, to differences in capture rate, prey rejection rate, and feeding activity, which we examine in the following.

\section{Prey capture and clearance rate}

Capture rate (normalized by cell concentration $=$ clearance rate) increased with prey size (within the range of 15$35 \mu \mathrm{m})$ at the start of the experiment (first five minutes), but this dependency rapidly disappeared (Fig. 2a) and clearance rate was subsequently controlled mainly by other factors. The dependency of ingestion and rejection behaviors on prey size similarly disappeared (Fig. 2b,c).

Average clearance rate (after $2 \mathrm{~h}$ ) varied by a factor of about 40 between prey species and strains (Fig. 3a, twoway ANOVA, $P<0.001)$. Compared to the control prey,
P. reticulatum (S13), copepods had significantly higher clearance rates on $K$. mikimotoi $(\mathrm{K}-0260, \mathrm{~S} 11)$ and $A$. tamarense (CCMP 1598, S3) and significantly low clearance rates on A. tamarense (Alex5, S1), K. brevis (CCMP 2229, S8), and $K$. brevis (CCMP 718, S9) (one-way ANOVA with HolmSidak post hoc test, $P<0.05)$. Clearance rates were in two cases similar between strains of the same species (A. pseudogonyaulax S4-5, $K$. brevis S8-9), and in other one case differed significantly and substantially between strains (A. tamarense S1-3) (one-way ANOVA with Holm-Sidak post hoc test, $P>0.05$ and $P<0.05$, respectively).

\section{Fraction of cells rejected}

Captured cells may be rejected leading to reduced consumption rate. The copepod captures the cell, examines it during a few $\mathrm{ms}$, and subsequently rejects it (Video $\mathrm{S} 1$ and $\mathrm{S} 2$ ). High rejection rate was the most consistent mechanism leading to low consumption rate (Fig. $3 \mathrm{~b}$ and Appendix S3: Fig. S1). Around $20 \%$ of captured nontoxic control cells were rejected by the copepods, but with one exception ( $A$. tamarense, Alex5, S1), all other prey were rejected at a similar (A. tamarense K-1471, S2) or higher to much higher rates. Especially, noteworthy is the very high rejection rates of A. pseudogonyaulax strains (S4 and S5) and also of $K$. mikimotoi (K-0260, S11) and D. acuminata (S12). This is the main reason that these cells are consumed at a low rate (Fig. 1). The low rejection rate of $A$. tamarense (Alex5, S1) and the high rejection rate of $K$. brevis (CCMP 718, S9) are based on very few observations $(n=72$ and 24 , respectively) due to low feeding activity and, thus, probably not representative.

\section{Feeding appendage activity}

A reduction in frequency and time fraction that $T$. longicornis beats its appendages to produce a feeding current

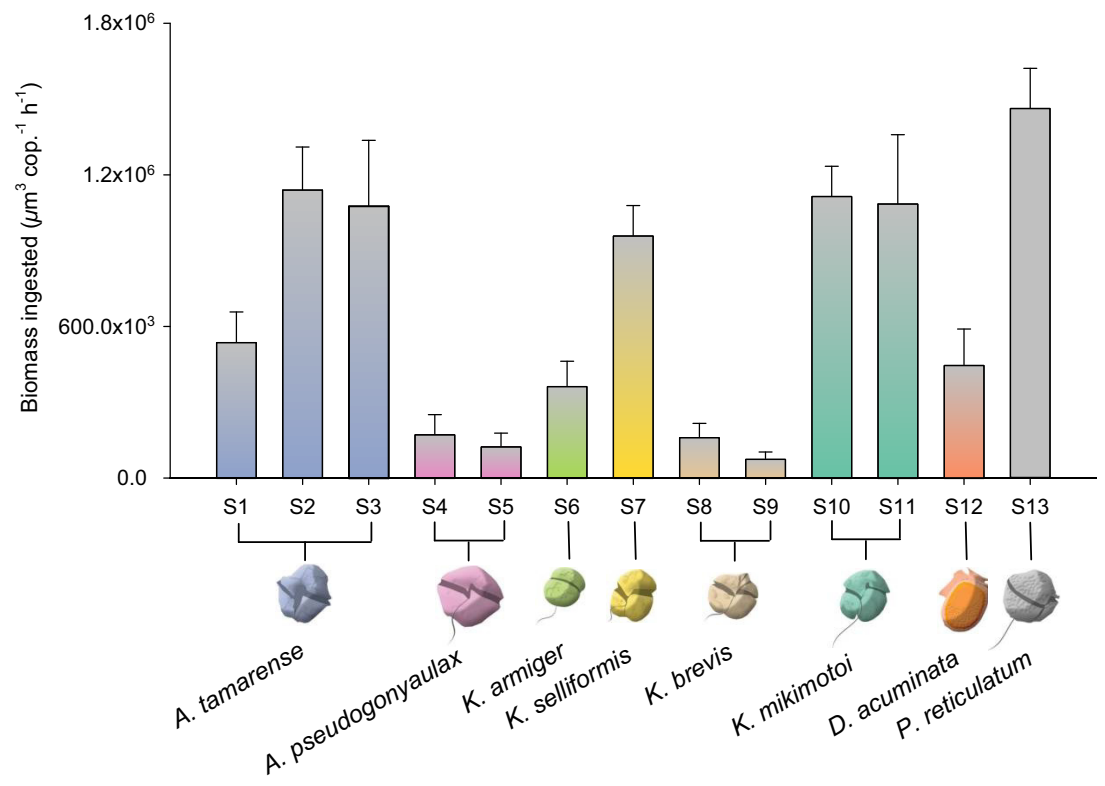

FIG. 1. Average biomass of algae ingested by Temora longicornis from 3rd to 24 th $\mathrm{h}$. Error bars showed standard errors $(n=9)$. 

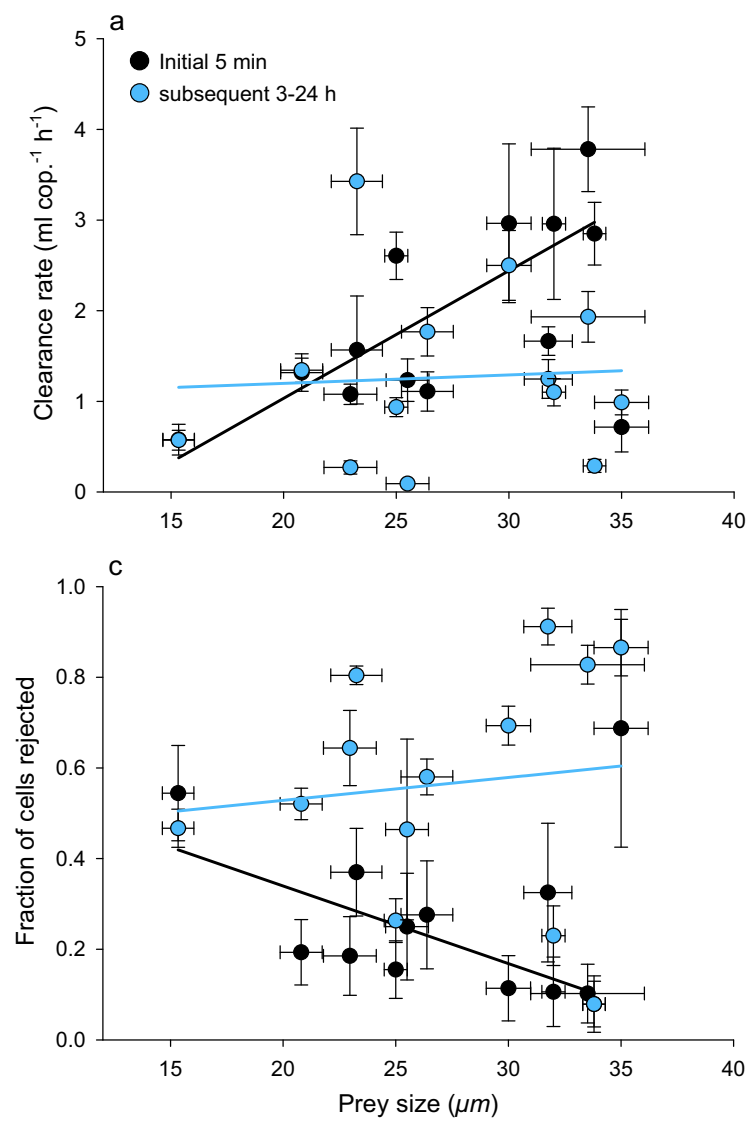

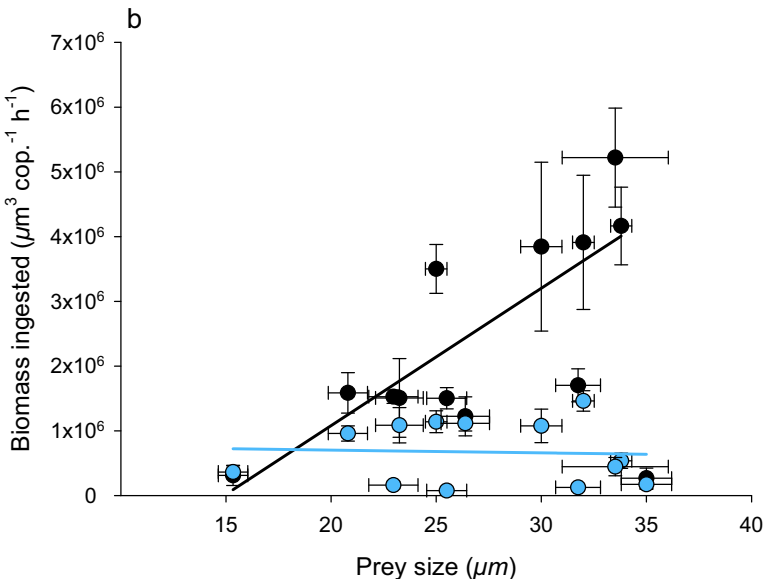

Prey size $(\mu m)$

FIG. 2. Relationship between prey size (PS) and clearance rate (CR; a), ingestion rate (IR; b), or rejection fraction (RF; c) of prey by Temora longicornis during the first $5 \mathrm{~min}$ after adding the prey (black dots) and after $2 \mathrm{~h}$ (average between 3rd and 24th hour) (blue dots). The regressions during the first 5 min (black curves) were statistically significant $\left(\mathrm{CR}=0.14 \times \mathrm{PS}-1.78, R^{2}=0.633 ; \mathrm{IR}=4.05 \times \mathrm{PS}-2.22\right.$, $\left.R^{2}=0.621 ; \mathrm{RF}=-3.19 \times \mathrm{PS}+4.66, R^{2}=0.504 ; P<0.05\right)$, but after $2 \mathrm{~h}$ (blue curves) they were insignificant $\left(R^{2}=0.003, P=0.852\right.$ for $\mathrm{CR} ; R^{2}=0.003, P=0.865$ for IR; $R^{2}=0.013, P=0.711$ for RF). Error bars showed standard errors $(n=3)$.

may similarly account for low consumption rate of prey cells. In most cases, the feeding appendages beat near $100 \%$ of the time at a frequency of about $30 \mathrm{~Hz}$ (Fig. 3c and Appendix S4: Fig. S1), but in a few cases, the activity was significantly reduced and/or variable over time (Fig. 3d and Fig. 4). Thus, upon introduction of $A$. tamarense (Alex5, S1) the copepod rapidly almost ceased beating its appendages, and when beating, it was at a significantly lower frequency (compared to control prey, two-way ANOVA with Holm-Sidak post hoc test, $P<0.05$, Fig. 3c). When offered $K$. brevis strains (S8 and $\mathrm{S} 9$ ), the beating frequency was reduced, although not significantly (compared to control prey, two-way ANOVA with Holm-Sidak post hoc test, $P>0.05$, respectively), and the fraction of time beating also rapidly dropped to very low levels, although subsequently increased again somewhat after a couple of hours (Fig. 4).

\section{Discussion}

After initial acclimation to the diet where prey clearance rate was governed mainly by prey size, all toxic algae were consumed at a lower or much lower rate than the nontoxic control prey, but the mechanisms by which feeding rates were reduced differed between algal species and strains. Significantly low consumption rates were in particular recorded for one strain of A. tamarense (Alex 5, S1), the two strains of $A$. pseudogonyaulax $(\mathrm{S} 4+5)$, and the two strains of $K$. brevis $(\mathrm{S} 8+9)$ and $D$. acuminata $(\mathrm{S} 12)$. In one case, A. tamarense (Alex 5, S1), the algae were consumed at a very low rate simply because the copepod ceased feeding. However, the most consistent responses to the toxic algae were high rejection rate, which were observed in 10 out of 12 species/strains, and in some cases combined with reduced feeding activity. This response suggests that whatever substances the algae are producing, they function as true grazer deterrents and constitute an evolutionary stable defense strategy. The dominance of deterrent effects is a novel discovery and different from most of the very many earlier reports of grazers becoming intoxicated or dying in response to exposure to toxic algae or reports from black box experiments that have been unable to distinguish between toxic and deterrent effects (Turner 2014). Indeed, there are only very few cases where grazer-deterrent effects have been convincingly demonstrated for a small selection of freshwater cyanobacteria (DeMott and Moxter 1991) and marine dinoflagellates (Teegarden 1999, Selander et al. 2006, Schultz and Kiørboe 2009).

In the case of the two K. brevis strains $(\mathrm{S} 8+9)$, the low clearance rates (Fig. 3a) cannot be explained solely by high rejection rates and reduced feeding activity, and must 

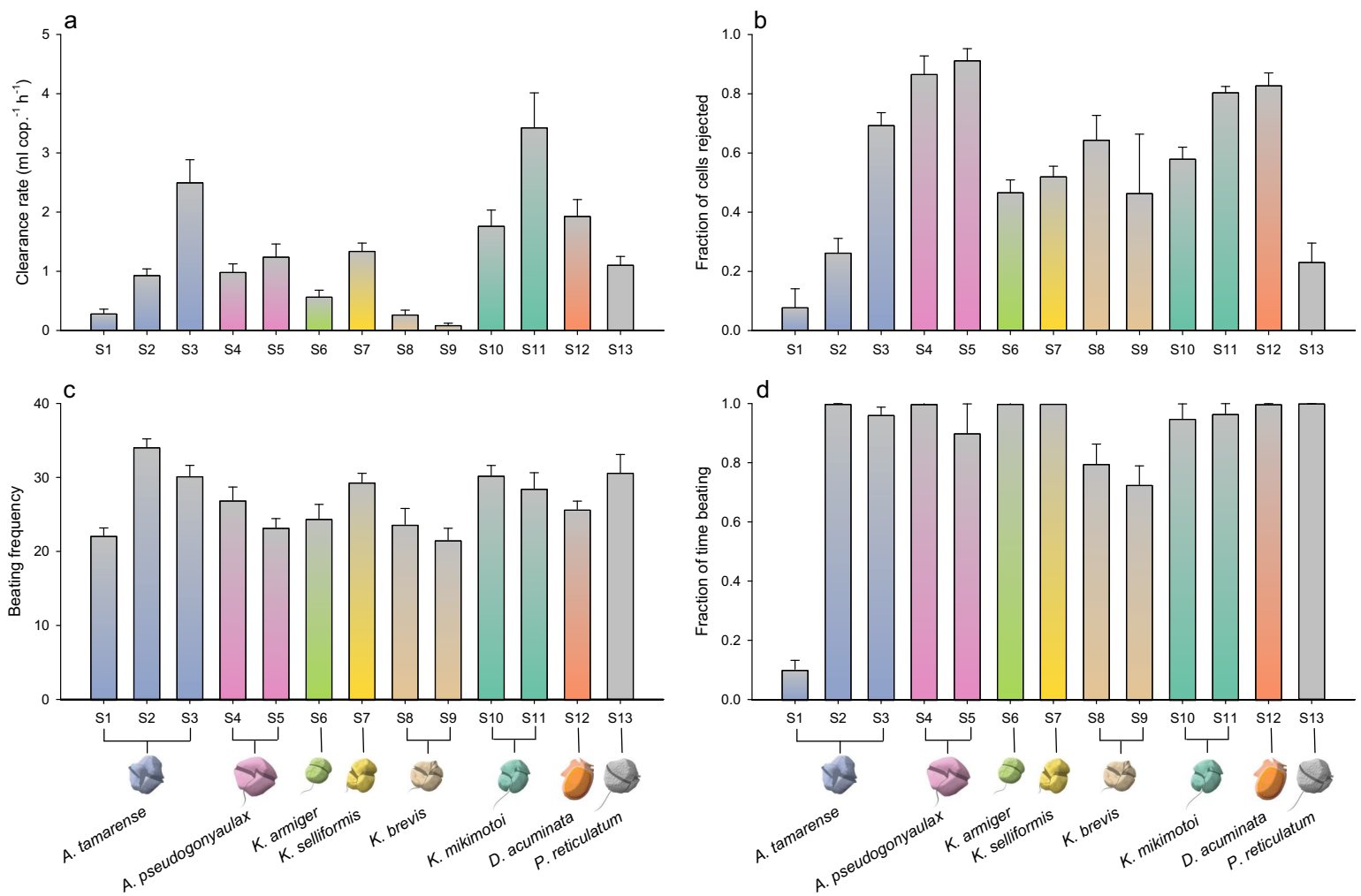

FIG. 3. Feeding behavior of Temora longicornis fed 13 strains of prey. Data ranged from the 3rd to 24th h. (a) average clearance rate of prey; (b) average proportions of cell that being rejected after being captured; (c) average frequency of feeding appendages beating; (d) average fraction of time that feeding appendages beating. Error bars in a, c, and d showed standard errors $(n=9)$, and error bars in b showed $95 \%$ Wilson Score Interval $(n=24-1,453)$.

depend on a precapture mechanism that may also constitute a response to a genuine grazer deterrent. Below we discuss the various mechanisms that lead to reduced cell consumption rates.

\section{Prey perception and handling}

Copepods perceive and capture prey cells individually (Koehl and Strickler 1981), and this allows the possibility that cells can be selected against based on their chemical or mechanical properties. The fact that cells of very similar shape and size, and even different strains of the same species, were rejected at significantly different rates strongly suggests that gustation and "taste" rather than the mechanical properties of the cells provide the cues for selection.

It is, however, unclear what that chemical cue is since intracellular substances that are toxic to the grazer cannot necessarily be detected from the outside of the cell. Also, variations in consumption rates are typically not clearly related to the measured toxicity profiles of the different phytoplankton strains compared, neither in copepods (Teegarden et al. 2008, Xu et al. 2017), other organisms (Tillmann and John 2002), nor in our experiments (Table 2 and Fig. 1). This suggests that the intracellular substances we measure may not necessarily be the substances to which the copepods and other grazers respond behaviorally and physiologically. It will be beneficial for the chemically defended prey to use exuded compounds to signal its toxicity to grazers, like "warning coloration" (aposematism), and in fact, such taste signals are required to account for our observations. Many dinoflagellates are known to release dissolved molecules, some of which with documented allelopathic effects but often poorly characterized chemically (Tillmann and John 2002, Tillmann et al. 2009), and such substances may constitute signal molecules that are detected by grazers. Whether or not these molecules are themselves toxic to the grazer, they should reflect genuine toxicity to the grazer if the cell is consumed. If the signal molecule is different from the toxic molecules, this would allow for the evolution of Batesian mimicry, that is, cheaters that produce the signal but not the costly toxin. Bioluminescence triggered by prey handling may be another way to signal toxicity (Lindström et al. 2017).

For the two $K$. brevis strains, the low capture and consumption rates cannot be fully accounted for by low feeding activity and high rejection rates, and an additional mechanism may operate. We consider two possibilities: (1) the copepod can identify these cells at distance through olfaction (smell) rather than gustation (taste) and decide not to capture them or (2) subsequent to consumption of some cells, the copepods' "motivation" to capture further cells of any kind declines, yet it keeps producing a feeding current to continuously sample for palatable prey. The former response would allow an evolutionary stable defense strategy in the phytoplankton while the latter would benefit competitors and cheaters equally well. It has earlier been suggested that organic molecules leaking from phytoplankton cells arriving in the sheared feeding current of a copepod 


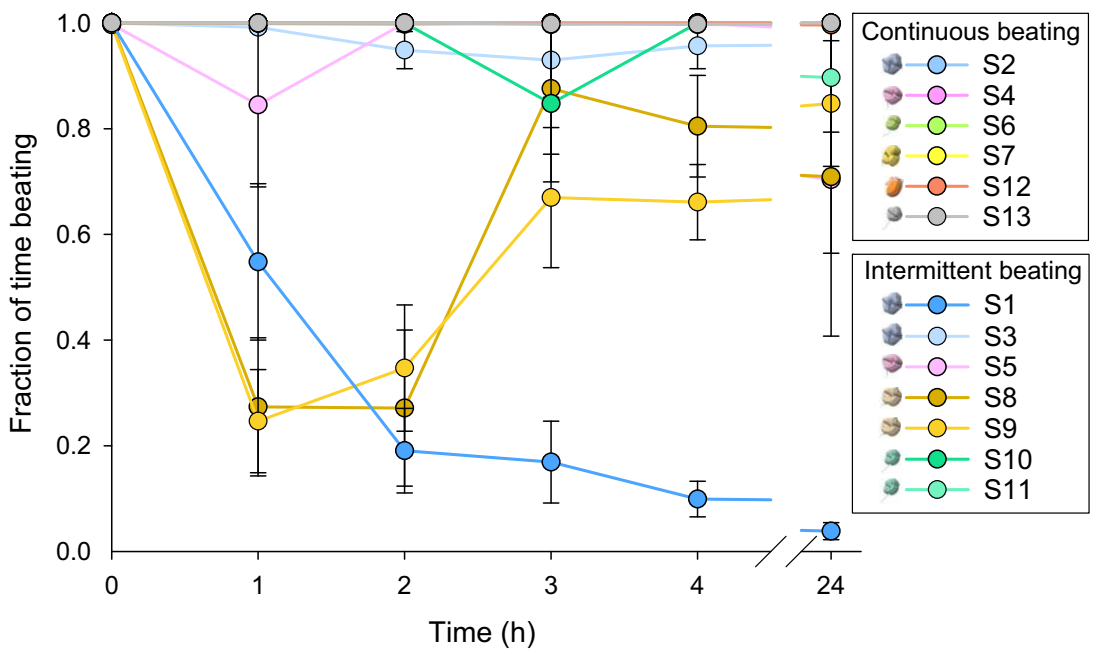

FIG. 4. Time budget of Temora longicornis beating appendages when fed different prey during a 24-h period. Strain numbers refer to Table 1. Error bars are standard errors $(n=3)$.

would reach the copepod before the cell itself and allow the copepod to perceive, respond to, and capture the cell (Strickler 1982, Andrews 1983, Jiang et al. 2002). Subsequent observations and theoretical analyses have, however, suggested that this is unfeasible as a general prey perception mechanism simply because the leakage rates of sugars, amino acids, or other molecules common to phytoplankton cells appear insufficient to provide a signal that significantly exceeds the background (Tiselius et al. 2013, Gonçalves and Kiørboe 2015, Kiørboe et al. 2016). However, more specific molecules, such as dimethyl sulfide (DMS) that is produced by some phytoplankton, may elicit responses at very low concentrations in both microorganisms (Strom et al. 2003, Seymour et al. 2010) and copepods (Steinke et al. 2006). Similarly, molecules signaling toxicity may be detected at homeopathic concentrations, thus allowing remote discrimination of toxic cells. There is some experimental evidence for this model (Schultz and Kiørboe 2009).

\section{Diversity of grazer responses and the role of toxins as a defense and competition tools in phytoplankton}

The responses of grazers to toxic algae appear to be highly diverse and variable both between and within grazer and phytoplankton species, for example, between different populations of the same grazer species and/or between different strains of the same phytoplankton species (Teegarden 1999, Colin and Dam 2002, Xu et al. 2017). It is striking from our studies and from many earlier reports that some cells with obvious toxic effects on copepods, such as cessation of feeding activity (e.g., the response of one strain of $A$. tamarense, S1, in the present experiments), other "sick" motor responses ((Lasley-Rasher et al. 2016, Xu et al. 2018), regurgitation of consumed cells (Sykes and Huntley 1987, Xu et al. 2017), or even death of the grazer (Rasmussen et al. 2017), are readily consumed, at least until the toxic effect materializes. The observation that toxic algae often have toxic rather than deterrent effects appears inconsistent with the idea that toxin production serves a defensive purpose (Flynn 2008). It is also striking that a phytoplankton species or strain that is toxic to one species or population of copepods is harmless to others (Colin and Dam 2002, Cohen et al. 2007). In some cases, such variability can be traced back to rapid evolutionary adaptation over just a few generations as has been demonstrated for the copepod Acartia tonsa to A. tamarense (Colin and Dam 2007) and Cochlodinium polykrikoides (Jiang et al. 2011) (see also review by Dam [2013]). Finally, we note that the diversity of toxin profiles within species is very high (Ichimi et al. 2002, Tillmann et al. 2009). How can we understand this perplexing diversity in grazer-alga interactions and in toxin profiles if toxin production mainly serves a defensive purpose?

The high diversity of grazer-phytoplankton interactions, the rapid evolutionary adaptation of grazers, and the multiple strains with radically different toxicity profiles found in many dinoflagellates may simply reflect different stages of an ever-ongoing evolutionary "arms race" between predators and their prey (Smetacek 2001) that results in a sort of "red queen" dynamics (Dieckmann et al. 1995). A grazer adapts to the toxin of a co-occurring toxic alga by becoming resistant to the toxin, and the alga may then evolve to produce new toxins with toxic or deterrent effects; the copepod subsequently evolves resistance that allows it to utilize an important food source, and so on. The constant mixing of water masses and populations in the ocean allows for a sustained high diversity of toxin profiles and behavioral and physiological grazer responses. An additional source of variability is that researchers often expose phytoplankton strains to grazer populations isolated from different geographical regions, and thus, organisms without a coevolutionary history. Finally, mimicry, as described above, may further add to the diversity of phytoplankton-grazer interactions. However, the dominance of deterrent over toxic grazer responses was revealed by our study.

Toxic substances released by some dinoflagellates may suppress the activity of their protozoan grazers (John et al. 2015) or the growth of their competitors (Jonsson et al. 2009) as a result of the collectively produced harmful concentration in the environment. Thus, toxic substances 
released by one strain of $A$. tamarense reduce the grazing from a predatory protist, but a nontoxic co-occurring strain enjoyed equal grazer protection (John et al. 2015). How do such "public goods" and other allelochemical substances that appear to work through cooperation evolve as defense or competition tools? Allelochemical effects typically materialize only at high densities of the defended or competing cells. Jonsson et al. (2009) argued that allelopathic effects may therefore be nonadaptive side effects of individual predator-prey interactions; thus, their evolution is not facilitated by their allelochemical effects. Allelopathic effects may emerge as the result of eco-evolutionary dynamics that depend on a trait that yield individual cells a selective advantage at low cell densities, that is, a "private good" (Driscoll et al. 2016). Such "private goods" may be offensive chemicals that kill or paralyze prey during direct cell-to-cell contact, as has been demonstrated in a few cases for mixotrophic dinoflagellates (Uchida et al. 1999, Adolf et al. 2007, Blossom et al. 2014), and with the collective effect only emerging at high cell densities. Alternatively, it may be toxic signal molecules that reduce the predation risk of individuals, as has been demonstrated here. While we have above argued that toxic cells should produce signal molecules to prevent them from being eaten, collective allelochemical effects would only emerge in cases where the signal molecule itself is toxic.

\section{ACKNOWLEDGMENTS}

We would like to thank Jack Melbye for maintaining the continuous copepod cultures, and thank Per Juel Hansen and Urban Tillmann for providing algal cultures. We also thank Bernd Krock and the staff at Alfred Wegener-Institut Helmholtz- Zentrum für Polarund Meeresforschung for toxin analysis of algal samples. We are grateful to Hans van Someren Gréve for his help with plotting charts. Jiayi $\mathrm{Xu}$ is supported by a $\mathrm{PhD}$ fellowship from China Scholarship Council. The Centre for Ocean Life is supported by the Villum Foundation.

\section{Literature Cited}

Adolf, J. E., D. Krupatkina, T. Bachvaroff, and A. R. Place. 2007. Karlotoxin mediates grazing by Oxyrrhis marina on strains of Karlodinium veneficum. Harmful Algae 6:400-412.

Alpermann, T. J., U. Tillmann, B. Beszteri, A. D. Cembella, and U. John. 2010. Phenotypic variation and genotypic diversity in a planktonic population of the toxigenic marine dinoflagellate Alexandrium tamarense (Dinophyceae). Journal of Phycology 46:18-32.

Andrews, J. C. 1983. Deformation of the active space in the low Reynolds number feeding current of calanoid copepods. Canadian Journal of Fisheries and Aquatic Sciences 40:1293-1302.

Baden, D. G., A. J. Bourdelais, H. Jacocks, S. Michelliza, and J. Naar. 2005. Natural and derivative brevetoxins: historical background, multiplicity, and effects. Environmental Health Perspectives 113:621-625.

Blossom, H. E., N. Daugbjerg, and P. J. Hansen. 2012. Toxic mucus traps: a novel mechanism that mediates prey uptake in the mixotrophic dinoflagellate Alexandrium pseudogonyaulax. Harmful Algae 17:40-53.

Blossom, H. E., N. G. Andersen, S. A. Rasmussen, and P. J. Hansen. 2014. Stability of the intra- and extracellular toxins of Prymnesium parvum using a microalgal bioassay. Harmful Algae 32: $11-21$.

Cembella, A. D. 1998. Ecophysiology and metabolism of paralytic shellfish toxins in marine microalgae. Pages $381-403$ in D. M.
Anderson, A. D. Cembella, and G. M. Hallegraeff, editors. Physiological ecology of harmful algal blooms, NATO-Advanced Study Institute Series, 41. Springer-Verlag, Heidelberg, Germany.

Cohen, J. H., P. A. Tester, and R. B. Forward. 2007. Sublethal effects of the toxic dinoflagellate Karenia brevis on marine copepod behavior. Journal of Plankton Research 29:301-315.

Colin, S. P., and H. G. Dam. 2002. Latitudinal differentiation in the effects of the toxic dinoflagellate Alexandrium spp. on the feeding and reproduction of populations of the copepod Acartia hudsonica. Harmful Algae 1:113-125.

Colin, S. P., and H. G. Dam. 2007. Comparison of the functional and numerical responses of resistant versus non-resistant populations of the copepod Acartia hudsonica fed the toxic dinoflagellate Alexandrium tamarense. Harmful Algae 6:875-882.

Dam, H. G. 2013. Evolutionary adaptation of marine zooplankton to global change. Annual Review of Marine Science 5: 349-370.

DeMott, W. R., and F. Moxter. 1991. Foraging Cyanobacteria by copepods: responses to chemical defense and resource abundance. Ecology 72:1820-1834.

Dieckmann, U., P. Marrow, and R. Law. 1995. Evolutionary cycling in predator-prey interactions: population dynamics and the red queen. Journal of Theoretical Biology 176:91-102.

Driscoll, W. W., J. D. Hackett, and R. Ferrière. 2016. Eco-evolutionary feedbacks between private and public goods: evidence from toxic algal blooms. Ecology Letters 19:81-97.

Flynn, K. J. 2008. Attack is not the best form of defense: lessons from harmful algal bloom dynamics. Harmful Algae 8:129-139

Gonçalves, R. J., and T. Kiørboe. 2015. Perceiving the algae: how feeding-current feeding copepods detect their nonmotile prey. Limnology and Oceanography 60:1286-1297.

Granéli, E., and P. J. Hansen. 2006. Allelopathy in harmful algae : a mechanism to compete for resources? Pages 189-201 in E. Granéli and J. T. Turner, editors. Ecology of harmful algae, ecological studies, Vol. 189. Springer-Verlag, Berlin, Germany.

Hillebrand, H., C.-D. Dürselen, D. Kirschtel, U. Pollingher, and T. Zohary. 1999. Biovolume calculation for pelagic and benthic microalgae. Journal of Phycology 35:403-424.

Hong, J., S. Talapatra, J. Katz, P. A. Tester, R. J. Waggett, and A. R. Place. 2012. Algal toxins alter copepod feeding behavior. PLoS ONE 7:e36845.

Ichimi, K., T. Suzuki, and A. Ito. 2002. Variety of PSP toxin profiles in various culture strains of Alexandrium tamarense and change of toxin profile in natural $A$. tamarense population. Journal of Experimental Marine Biology and Ecology 273:51-60.

Jiang, H. H., T. R. Osborn, and C. Meneveau. 2002. Chemoreception and the deformation of the active space in freely swimming copepods: a numerical study. Journal of Plankton Research 24:495-510.

Jiang, X., D. J. Lonsdale, and C. J. Gobler. 2011. Rapid gain and loss of evolutionary resistance to the harmful dinoflagellate Cochlodinium polykrikoides in the copepod Acartia tonsa. Limnology and Oceanography 56:947-954.

John, U., U. Tillmann, J. Hulskotter, T. J. Alpermann, S. Wohlrab, and D. B. Van de Waal. 2015. Intraspecific facilitation by allelochemical mediated grazing protection within a toxigenic dinoflagellate population. Proceedings of the Royal Society B 282:20141268

Jonsson, P. R., H. Pavia, and G. Toth. 2009. Formation of harmful algal blooms cannot be explained by allelopathic interactions. Proceedings of the National Academy of Sciences of the United States of America 106:11177-11182.

Kamiyama, T., and T. Suzuki. 2009. Production of dinophysistoxin1 and pectenotoxin-2 by a culture of Dinophysis acuminata (Dinophyceae). Harmful Algae 8:312-317.

Kiørboe, T., R. J. Gonçalves, D. Couespel, H. van Someren Gréve, E. Saiz, and P. Tiselius. 2016. Reply to comment: prey perception in feeding-current feeding copepods. Limnology and Oceanography 61:1169-1171. 
Koehl, M. A. R., and J. R. Strickler. 1981. Copepod feeding currents: food capture at low Reynolds number. Limnology and Oceanography 26:1062-1073.

Lasley-Rasher, R. S., K. Nagel, A. Angra, and J. Yen. 2016. Intoxicated copepods: ingesting toxic phytoplankton leads to risky behaviour. Proceedings of the Royal Society B: Biological Sciences 283:20160176.

Lee, H. H., M. N. Molla, C. R. Cantor, and J. J. Collins. 2010. Bacterial charity work leads to population-wide resistance. Nature 467:82-85.

Lewis Jr, W. M. 1986. Evolutionary interpretations of allelochemical interactions in phytoplankton algae. American Naturalist 127:184-194.

Lindström, J., W. Grebner, K. Rigby, and E. Selander. 2017. Effects of predator lipids on dinoflagellate defence mechanisms increased bioluminescence capacity. Scientific Reports 7:13104.

Miles, C. O., A. L. Wilkins, D. J. Stirling, and A. L. MacKenzie 2000. New analogue of Gymnodimine from a Gymnodinium species. Journal of Agricultural and Food Chemistry 48:1373-1376.

Naar, J. P., et al. 2007. Brevetoxins, like ciguatoxins, are potent ichthyotoxic neurotoxins that accumulate in fish. Toxicon 50:707723.

Neely, T., and L. Campbell. 2006. A modified assay to determine hemolytic toxin variability among Karenia clones isolated from the Gulf of Mexico. Harmful Algae 5:592-598.

Nielsen, L., B. Krock, and P. Hansen. 2012. Effects of light and food availability on toxin production, growth and photosynthesis in Dinophysis acuminata. Marine Ecology Progress Series 471:37-50.

Nielsen, L. T., B. Krock, and P. J. Hansen. 2013. Production and excretion of okadaic acid, pectenotoxin-2 and a novel dinophysistoxin from the DSP-causing marine dinoflagellate Dinophysis acuta - Effects of light, food availability and growth phase. Harmful Algae 23:34-45.

Rasmussen, S. A., S. B. Binzer, C. Hoeck, S. Meier, L. S. de Medeiros, N. G. Andersen, A. Place, K. F. Nielsen, P. J. Hansen, and T. O. Larsen. 2017. Karmitoxin: an amine-containing polyhydroxy-polyene toxin from the marine dinoflagellate Karlodinium armiger. Journal of Natural Products 80:1287-1293.

Sala-Pérez, M., T. J. Alpermann, B. Krock, and U. Tillmann. 2016. Growth and bioactive secondary metabolites of arctic Protoceratium reticulatum (Dinophyceae). Harmful Algae 55:85-96.

Satake, M., M. Shoji, Y. Oshima, H. Naoki, T. Fujita, and T. Yasumoto. 2002. Gymnocin-A, a cytotoxic polyether from the notorious red tide dinoflagellate, Gymnodinium mikimotoi. Tetrahedron Letters 43:5829-5832.

Satake, M., Y. Tanaka, Y. Ishikura, Y. Oshima, H. Naoki, and T. Yasumoto. 2005. Gymnocin-B with the largest contiguous polyether rings from the red tide dinoflagellate, Karenia (formerly Gymnodinium) mikimotoi. Tetrahedron Letters 46:3537-3540.

Satake, M., A. Campbell, R. M. Van Wagoner, A. J. Bourdelais, H. Jacocks, D. G. Baden, and J. L. C. Wright. 2009. Brevisin: an aberrant polycyclic ether structure from the dinoflagellate Karenia brevis and its implications for polyether assembly. Journal of Organic Chemistry 74:989-994.

Schultz, M., and T. Kiørboe. 2009. Active prey selection in two pelagic copepods feeding on potentially toxic and non-toxic dinoflagellates. Journal of Plankton Research 31:553-561.

Seki, T., M. Satake, L. Mackenzie, H. F. Kaspar, and T. Yasumoto. 1995. Gymnodimine, a new marine toxin of unprecedented structure isolated from New Zealand oysters and the dinoflagellate, Gymnodinium sp. Tetrahedron Letters 36:7093-7096.

Selander, E., P. Thor, G. Toth, and H. Pavia. 2006. Copepods induce paralytic shellfish toxin production in marine dinoflagellates. Proceedings of the Royal Society B 273:1673-1680.

Selander, E., T. Fagerberg, S. Wohlrab, and H. Pavia. 2012. Fight and flight in Dinoflagellates? Kinetics of simultaneous grazerinduced responses in Alexandrium tamarense. Limnology and Oceanography 57:58-64.

Selander, E., J. Kubanek, M. Hamberg, M. X. Andersson, G. Cervin, and H. Pavia. 2015. Predator lipids induce paralytic shellfish toxins in bloom-forming algae. Proceedings of the National Academy of Sciences of the United States of America 112:6395-6400.

Seymour, J. R., R. Simó, T. Ahmed, and R. Stocker. 2010. Chemoattraction to dimethylsulfoniopropionate throughout the marine microbial food web. Science 329:342-345.

Smetacek, V. 2001. A watery arms race. Nature 411:745.

Steinke, M., J. Stefels, and E. Stamhuis. 2006. Dimethyl sulfide triggers search behavior in copepods. Limnology and Oceanography 51:1925-1930.

Strickler, J. R. 1982. Calanoid copepods, feeding currents, and the role of gravity. Science 218:158-160.

Strom, S., G. Wolfe, A. Slajer, S. Lambert, and J. Clough. 2003. Chemical defense in the microplankton II: inhibition of protist feeding by $\beta$-dimethylsulfoniopropionate (DMSP). Limnology and Oceanography 48:230-237.

Suikkanen, S., A. Kremp, H. Hautala, and B. Krock. 2013. Paralytic shellfish toxins or spirolides? The role of environmental and genetic factors in toxin production of the Alexandrium ostenfeldii complex. Harmful Algae 26:52-59.

Sykes, P. F., and M. E. Huntley. 1987. Acute physiological reactions of Calanus pacificus to selected dinoflagellates: direct observations. Marine Biology 94:19-24.

Tatters, A. O., H. I. Muhlstein, and C. R. Tomas. 2010. The hemolytic activity of Karenia selliformis and two clones of Karenia brevis throughout a growth cycle. Journal of Applied Phycology 22:435442.

Teegarden, G. J. 1999. Copepod grazing selection and particle discrimination on the basis of PSP toxin content. Marine Ecology Progress Series 181:163-176.

Teegarden, G. J., R. G. Campbell, D. T. Anson, A. Ouellett, B. A. Westman, and E. G. Durbin. 2008. Copepod feeding response to varying Alexandrium spp. cellular toxicity and cell concentration among natural plankton samples. Harmful Algae 7:33-44.

Thornton, D. C. O. 2002. Individuals, clones or groups? phytoplankton behaviour and units of selection. Ethology Ecology and Evolution 14:165-173.

Tillmann, U. 2003. Kill and eat your predator: a winning strategy of the planktonic flagellate Prymnesium parvum. Aquatic Microbial Ecology 32:73-84.

Tillmann, U., and U. John. 2002. Toxic effects of Alexandrium spp. on heterotrophic dinoflagellates: an allelochemical defence mechanism independent of PSP-toxin content. Marine Ecology Progress Series 230:47-58.

Tillmann, U., T. L. Alpermann, R. C. da Purificação, B. Krock, and A. Cembella. 2009. Intra-population clonal variability in allelochemical potency of the toxigenic dinoflagellate Alexandrium tamarense. Harmful Algae 8:759-769.

Tiselius, P., E. Saiz, and T. Kiørboe. 2013. Sensory capabilities and food capture of two small copepods, Paracalanus parvus and Pseudocalanus sp. Limnology and Oceanography 58:1657-1666.

Triki, H. Z., M. laabir, P. Moeller, N. Chomérat, and O. K. DalyYahia. 2016. First report of goniodomin A production by the dinoflagellate Alexandrium pseudogonyaulax developing in southern Mediterranean (Bizerte Lagoon, Tunisia). Toxin 111:91-99.

Turner, J. T. 2014. Planktonic marine copepods and harmful algae. Harmful Algae 32:81-93.

Turner, J. T., and P. A. Tester. 1997. Toxic marine phytoplankton, zooplankton grazers, and pelagic food webs. Limnology and Oceanography 42:1203-1214.

Uchida, T., S. Toda, Y. Matsuyama, M. Yamaguchi, Y. Kotani, and T. Honjo. 1999. Interactions between the red tide dinoflagellates Heterocapsa circularisquama and Gymnodinium mikimotoi in laboratory culture. Journal of Experimental Marine Biology and Ecology 241:285-299.

Uye, S., and K. Takamatsu. 1990. Feeding interactions between planktonic copepods and red-tide flagellates from japanese coastal waters. Marine Ecology Progress Series 59:97-107.

West, S. A., A. S. Griffin, A. Gardner, and S. P. Diggle. 2006. Social evolution theory for microorganisms. Nature Reviews Microbiology 4:597-607. 
Wittstock, U., and J. Gershenzon. 2002. Constitutive plant toxins and their role in defense against herbivores and pathogens. Current Opinion in Plant Biology 5:300-307.

Xu, J., P. J. Hansen, L. T. Nielsen, B. Krock, U. Tillmann, and T. Kiørboe. 2017. Distinctly different behavioral responses of a copepod, Temora longicornis, to different strains of toxic dinoflagellates, Alexandrium spp. Harmful Algae 62:1-9.

Xu, J., L. T. Nielsen, and T. Kiørboe. 2018. Foraging response and acclimation of ambush feeding and feeding-current feeding copepods to toxic dinoflagellates. Limnology and Oceanography 63:1449-1461.

\section{SUPPORTING INFORMATION}

Additional supporting information may be found in the online version of this article at http://onlinelibrary.wiley.com/doi/10.1002/ecy. 2479/suppinfo 